\title{
MEMBANGUN NEGARA HUKUM YANG KUAT MELALUI PENYELENGGARAAN SISTEM PERADILAN PIDANA BERBASIS KONSTITUSIONALITAS
}

\author{
Fanny Tanuwijaya \\ Pengajar Fakultas Hukum Universitas Jember \\ Tegal Boto Lor, Sumbersari, Jember Regency, Jawa Timur, 68121 \\ Email: fanifhunej17@gmail.com
}

\begin{abstract}
Indonesia has been trying to transform their institution to become a strong legal state. There are a number of obstacles encountered by every law enforcement officer in the effort to build this country. There are plenty of law enforcement officers who failed to show themselves as a committed officer in implementing one of the principles of "Nawa Cita" promoted by President Joko Widodo. Criminal justice system is part of Indonesian legal systems considered as unsuccessful in realizing this hope because its organizers have not comprehensively implemented constitution principles in their performance.
\end{abstract}

Keywords: state of law, administration, criminal justice system, constitution

\begin{abstract}
ABSTRAK
Negara Indonesia terus berupaya membangun supaya menjadi negara hukum yang kuat. Ada banyak dan beragam hambatan yang ditemui oleh setiap aparat penegak hukum dalam upaya membangun negara ini. Tidak sedikit aparat penegak hukum yang gagal menunjukkan dirinya sebagai aparat yang punya komitmen dalam salah satu cita dari "nawa cita" Presiden Joko Widodo. Penyelenggaraan sistem peradilan pidana merupakan bagian dari sistem hukum Indonesia yang seringkali diposisikan belum berhasil mewujudkan cita-cita "nawa cita" akibat para penyelenggaranya yang belum menjalankan prinsip konstitusionalitas dalam kinerjanya.

Kata Kunci: negara hukum, penyelenggaraan, sistem peradilan pidana, konstitusi
\end{abstract}

\section{PENDAHULUAN}

Nawa cita Presiden Joko Widodo, butir keempat yang berbunyi menolak negara lemah dengan melakukan reformasi sistem dan penegakan hukum yang bebas korupsi, bermartabat, dan terpercaya, dapatlah terbaca sebagai cita-cita Presiden Jokowi terhadap terwujudnya era baru dunia hukum di negeri ini.

Dari nawa cita itu, muncul pertanyaan mampukahPresidenJokowi mewujudkannya? atau apakah di lima tahun pemerintahanya ini, negara Indonesia yang kuat (bukan negara lemah) berbasis yuridis ada tanda-tanda berhasil dikonstruksinya?

Presiden Jokowi jelas menginginkan terbentuknya suatu negara yang kuat, yang esensi kekuatannya terletak pada soal pembentukan sistem dan penegakan hukum. meski demikian, tidak mudah mewujudkan cita-cita demikian, karena dalam cita-cita mulia di negeri ini, ada banyak pihak yang tidak atau belum berkeinginan untuk mendukungnya.

Mewujudkan suatu bangunan yang kuat dalam kehidupan bernegara atau bermasyarakat selalu menghadapi tantangan yang tidak ringan, khususnya yang bersumber dari pihakpihak yang seharusnya memberikan (menunjukkan) sikap dan perilaku terpuji. Namun, mereka ini justru hadir sebagai pihak yang menjadi kendala yang menghambat atau menggagalkannya. Mereka ini menjadi subyek yang membuat bangunan negara ini tidak menjadi kuat, dan sebaliknya 
menghadirkan berbagai macam penyakit yang melemahkan negara. ${ }^{1}$

\section{PEMBAHASAN}

\section{Tuntutan Membangun Negara Hukum}

Tampaknya keinginan Presiden Jokowi itu tidak mudah diwujudkan jika dikaitkan dengan realitas sosial. Fakta terbaca, bahwa sebagian elemen sosial belum taat normanorma yuridis atau rentan melakukan pembangkangan hukum (legal discobidience). Kasus main hakim sendiri (eigenrichting) yang dari waktu ke waktu kian "mengerikan", seperti kasus membakar dan membunuh atau melakukan penganiayaan massal terduga pelanggar hukum adalah indikasi kasus mengenai duri membangun negara kuat berbasis ketaatan norma yuridis.

Kasus main hakim sendiri merupakan potret redupnya penegakan hukum di negeri ini. Redupnya penegakan hukum ini tentu saja berimbas pada keadilan. Di tangan penegak hukum yang bermental lemah, keadilan tidak mungkin bisa ditegakkan.

Dalam ranah itu, jelas tugas tidak ringan diemban pemerintahan Presiden Jokowi. Jokowi terus dituntut publik supaya berusaha sekuat tenaga untuk "merestorasi" penegakan hukum yang tercoreng oleh ulah elemen sosial dan hukum yang salah satunya mengakibatkan redupnya keadilan.

Masyarakat tidak akan gampang terpancing melakukan main hakim sendiri kalau dalam realitas kesehariannya mereka dihadapkan dengan pola law in action yang menghidupkan dan mengembangkan keadilan.

Bacaan terhadap pelaksanaan sistem peradilan yang tidak memberikan keadilan sebesar-besarnya untuk pencari keadilan dapat membuatnya menyimpan amarah atau bahkan kebencian terhadap siapa saja yang menjadi pelanggar hukum atau "penjarah" hak-haknya, termasuk "penjahat kelas teri".
Hukum dituntut oleh rakyat harus dijadikan sebagai aturan main dalam penyelenggaraan pemerintahan negara, terutama dalam memelihara ketertiban, harmonisasi sosial, dan perlindungan terhadap hak-hak warganya.

Mereka bercita-cita, bahwa di negara berdasarkan atas hukum ini, setiap perbuatan apapun dan dari siapapun, yang dikategorikan berlawanan dengan norma yuridis, khusunya pelaku "kejahatan krah putih" (white collar crime) wajib hukumnya untuk dipertanggungjawabkan secara egaliter dan berkeadilan. Jika ini bisa diwujudkan, maka penegakan hukumnya layak distigma berkualitas, pasalnya diantaranya mampu memberi kesejatian keadilan sebesar-beaarnya untuk rakyat.

Dapat dipahami, bahwa dalam negara yang berdasarkan atas hukum, dalam hal ini hukum harus dimaknai sebagai kesatuan hirarkis tatanan norma hukum yang berpuncak pada konstitusi. Hal ini berarti bahwa dalam suatu negara hukum menghendaki adanya supremasi konstitusi. Supremasi konstitusi, di samping merupakan konsekuensi dari konsep negara hukum, sekaligus merupakan pelaksanaan demokrasi karena konstitusi adalah wujud perjanjian sosial tertinggi. ${ }^{2}$

Berdasarkan teori kontrak sosial, untuk memenuhi hak-hak tiap manusia, tidak mungkin dicapai masing-masing orang secara individual, tetapi harus bersamasama. Maka, dibuatlah perjanjian sosial yang berisi tentang tujuan bersama, batas-batas hak individual, dan siapa yang bertanggung jawab untuk pencapaian tujuan tersebut dan menjalankan perjanjian yang telah dibuat dengan batas-batasnya. Perjanjian tersebut diwujudkan dalam bentuk konstitusi sebagai hukum tertinggi (supremasi yuridis) di suatu negara (the supreme law of the land), yang kemudian dielaborasi secara konsisten dalam hukum dan diskresi negara. $^{3}$

1 Suhardiman, (16 Mei 2016), “Eksaminasi Membangun Era Baru Bernegara”, Surabaya; Lembaga Kajian Strategis Indonesia (LKSI). Hlm. 2.

2 Asshiddiqie, Jimly. Konstitusi dan Konstitusionalisme Indonesia, Edisi Revisi, Jakarta; Konstitusi Press, 2005. Hlm. 152-162.

3 Asshiddiqie, Jimly. (2008), Menuju Negara Hukum Yang Demokratis, Jakarta;Sekretariat Jendera dan Kepaniteraan Mahkamah Konstiusi. Hlm. 532. 
Perlu dipahami, bahwa didalam masa sekarang untuk konsep equality before the law telah bersepakat dengan konsep-konsep Hak Asasi manusia yang tertuang didalam UDHR (Universal Deklaration of Human Right) dan konvenan Internasional mengenai hak-hak sosial politik 1966 (ICCPR) memberikan hak keseteraaan didepan hukum dan perlindungan yang sama didepan hukum. Kesederajatan hukum berarti bahwa setiap orang tidak dapat didiskriminasi berdasarkan ras, warna kulit, jenis kelamin, bahasa, agama, pandangan politik atau lainnya, latar belakang kebangsaan atau sosial, kekayaan, status kelahiran atau lainnya, berkaitan dengan perlakuan terhadap mereka didepan hukum. Dalam kenyataan atau realitas, hal ini meletakan kewajiban kepada negara pihak menjamin bahwa semua kelompok tunduk pada hukum yang sama serta memiliki hak yang sama. Pengecualian bisa saja terjadi bagi penduduk asli tunduk pada undang-undang khusus yang dibuat guna melindungi hak atas tanah tradisional ataupun penggunaannya. Hak hukum (legal right) bagi kelompok yang lemah seperti wanita, anak dibawah umur, orang lanjut usia serta penyandang cacat khusus dilindungi dalam konvensi terkait. ${ }^{4}$

Selain itu, jika berpijak pada identitas konstitusionalitas Indonesia sebagai negara hukum, semua problem besar bangsa yang berelasi dengan kasus-kasus hukum, haruslah diselesaikan secara yuridis, tanpa memilah atau memilih kasusnya, sehingga semestinya penyelesaian kasusnya mendapatkan perlakuan yang sama.

\section{Konstitusi dan Criminal Justice System}

Dalam konstruksi idealitas sistem peradilan pidana (criminal justice system) secara egaliter dan inklusif, serta demokratis, kasus apapun, apalagi kasus kejahatan yang bersifat istimewa (exstra ordinary crime), harus ditangani secara non diskriminatif, atau berbasiskan penegakan keadilan untuk semua (justice for all). Basis ini identik dengan prinsip konstitusionalitas yang menekankan penyelenggaraan hukum di negara demokratis.

Carter dan Herz ${ }^{5}$ mengonstruksi idealitas demokrasi sebagai pemerintahan yang dicirikan oleh dan dijalankannya melalui prinsipprinsip: pertama, pembatasan terhadap tindakan pemerintah untuk memberikan perlindungan bagi individu dan kelompok dengan jalan menyusun pergantian pimpinan secara berkala, tertib dan damai, dan melalui alat-alat perwakilan rakyat yang efektif; Kedua, adanya sikap toleransi terhadap pendapat yang berlawanan, ketiga, persamaan di depan hokum yang diwujudkan dengan sikap tunduk kepada rule of law tanpa membedakan kedudukan politik; keempat, adanya pemilihan yang bebas dengan disertai adanya model perwakilan yang efektif; kelima, kebebasan partisipasi dan beroposisi bagi partai politik, organisasi kemasyarakatan, masyarakat dan perseorangan serta prasarana pendapat umum semacam pers dan media massa, keenam, adanya penghormatan terhadap hak rakyat untuk menyatakan pandangannya betapa pun tampak salah dan tidak populernya pandangan itu; dan ketujuh dikembangkannya sikap menghargai hak-hak minoritas dan perorangan dengan lebih mengutamakan penggunaan cara-cara persuasif dan diskusi daripada koersif dan represif.

Siapapun elemen bangsa yang memahami ruh konstitusi, yang diantaranya mengajarkan prinsip persamaan derajat di depan hukum (equality before the law), tentulah akan berpikiran kritis, bahwa kinerja aparat penegak hukum haruslah berlandasakan prinsip hukum berbasis kesederajatan atau keberkeadilan. Kalau prinsip ini belum dijalankan, maka aparat wajib "disemangati" supaya maju terus untuk memberi keadilan pada bangsa ini.

Idealnya paradigma kebersederajatan harus digunakan oleh komunitas siapapun di negara

\footnotetext{
4 Erica Harper, (2009), International law and standard applicable in natural disaster situation, Jakarta, Gramedia. Hlm. 32.

5 Carter, Gwendolen M. dan Herz,Peranan, John. (1982), Pemerintah dalam Masyarakat Masa Kini, dalam Miriam Budiardjo, Masalah Kenegaraan, Jakarta; Gramedia. Hlm. 86 - 87.
} 
ini, khususnya elemen yudisial bahwa siapapun orangnya yang tersangkut kasus hukum, wajib dipertanggungjawabkan dengan tidak membedakan kasta politik, ideologi, dan ekonomi supaya secara psikologis, rakyat mendapatkan kepuasan dan bukan kekecewaan berlarut.

Siapapun berhak atas perlakuan egaliter dan berkeadilan dalam ranah penegakan sistem peradilan pidana (criminal justice system). Kalau keadilan bisa ditegakkan, kata Mayers, negara dan pemerintahan apapun jenisnya, bukan hanya bisa diselamatkan, tetapi juga bisa diantarkan menuju masa depan mencerahkan dan berkeadaban. ${ }^{6}$ Sistem peradilan menjadi penentu sebagian bangunan negara, yang ketika sistem ini dijalankan dengan benar, maka sebagian bangunan negara ini menjadi kuat.

Sistem peradilan pidana harus menjadi sistem yang berjalan dengan kekuatannya, yang dengan kekuatannya ini dapat menjadi kekuatan yang menentukan bangunan negara sekarang atau di masa-masa mendatang, bilamana pilar-pilar yang mendapatkan kepercayaan menunjukkan kinerja yang berbasis memperkuatnya.

Pasal 7 Universal Declaration of Human Right (UDHR) disebutkan, bahwa semua orang sama di depan hukum dan berhak atas perlindungan hukum yang sama tanpa diskriminasi. Semua berhak atas perlindungan yang sama terhadap setiap bentuk diskriminasi yang bertentangan dengan Deklarasi ini, dan terhadap segala hasutan yang mengarah pada diskriminasi semacam ini.

Deklarasi HAM itu juga sudah dibahasakan dalam konstitusi Indonesia dalam Pasal 27 UUD 45, bahwa segala warga negara berkedudukan sama di depan hukum dan pemerintahan. Makna Pasal ini tidak sulit dipahami oleh publik, bahwa di hadapan hukum, tidak boleh ada yang didiskriminasian. Setiap orang mempunyai kedudukan sederajat atau egaliter.

Setiap aparat penegak hukum mempunyai amanat dalam membumikan instrumen HAM internasional dan prinsip agung konstitusi. Penegakan ini bukan bertarget pembelaan kepentingan eksklusif seseorang atau sekelompok orang dan dan bukan karena desakan sejumlah orang, melainkan demi tegaknya keadilan untuk semua.

Franz Magnis Suseno pernah mengingatkan, bahwa secara moral politik ada empat alasan utama orang menuntut agar negara diselenggarakan (dijalankan) berdasarkan atas hukum yaitu: pertama, kepastian hukum, kedua, tuntutan tuntutan perlakuan yang sama, ketiga, legitimasi demokrasi, dan keempat, tuntutan akal budi. ${ }^{7}$

Pikiran Suseno tersebut menunjukkan pada kita, bahwa jaminan kepastian dan perlakuan yuridis bernafas egaliter sangatlah menentukan konstruksi negara berkedaulatan hukum yang mengalirkan atau mendistribusikan keadilan.

Negara tidak akan dikenal dan dijadikan rumah besar oleh rakyat, ketika penerapan atau penegakan hukum tidak memberikan kepastian dan perlakuan berbasis kesederajatan, dan sebaliknya negara bisa jadi ajang praktik barbarian dan kebiadaban secara individual atau kelompok ketika negara lewat pilar yudisialnya gagal membumikan keadilan.

Sebagai komparasi analisis bahwa pihak yang bereaksi terhadap negara Polizei ialah "orang-orang kaya dan cendikiawan". Orang kaya (borjuis) dan cendikiawan ini menginginkan agar hak-hak kebebasan pribadi tidak diganggu, yang mereka inginkan ialah mereka hanya ingin kebebasan mengurusi kepentingannya sendiri. Konkritnya ialah agar agar permasalahan perekonomian menjadi urusan mereka dan negara tidak ikut campur dalam penyelenggaraan tersebut. ${ }^{8}$ Dalam ranah inilah, ada egoisme di kalangan elitis, khususnya kalangan elitis ekonomi yang menginginkan sikap atau sepak terjangnya tidak perlu dikendalikan oleh kekuatan apapun, termasuk oleh kekuatan yuridis.

Disitulah hukum bisa dikalahkan oleh kekuatan elitis borjuis, sementara yang

6 Saksono, Haryo. (2018) Membangun Negeri Untuk Rakyat, Jakarta; Gerbang Ilmu. Hlm. 2.

7 Suhardiman, Op.Cit. Hlm. 3.

8 Russel, Bertrand. (2002) Sejarah Filssafat Barat, Yogyakarta; Pustaka Pelajar. Hlm. 928. 
berlaku adalah keinginan seseorang atau sejumlah orang yang memperlakukan dirinya sebagai hukum itu sendiri, sehingga meskipun perbuatannya merugikan orang lain, atau di mata orang lain sebagai kejahatan serius, sistem peradilan pidana gagal mempertaggungjawabkannya.

Rakyat atau kalangan pencari keadilan (justiabelen) merupakan pilar sakral dan fundamental yang menentukan syarat berdirinya negara. Ketika rakyat tidak mendapatkan kepastian yuridis mengenai misalnya kasus-kasus bertemakan pelanggaran hak-haknya atau akrab diberi tontonan ketidakadilan, maka logis, meski abnormal, jika rakyat mereaksinya dengan cara-cara yang bisa saja berlawanan dengan hukum atau bahkan melawan normanorma hukum pidana.

Di tangan elemen yudisial, kasus-kasus sensitif yang sejak awal muncul sebagai kasus istimewa yang menyita perhatian masyarakat, dalam perjalanan waktu dan adanya ledakan (booming) kasus, semakin tergeser secara gradual mengisi ranah ketidakjelasan, sehingga terkesan atau barangkali faktanya menjadi kasus mengambang (floating case), yang bisa menggumpalkan (mengompilasikan) dan meledakkan amarah publik.

Para "penjahat berdasi" misalnya sudah membuat kesengsaraan serius dan masif di negeri ini, padahal diantara mereka paham hukum dan ilmu-ilmu agama. Mereka telah memproduksi banyak kesengsaraan rakyat dengan cara mengkleptokrasi sumberdaya strategis bangsa yang bukan menjadi haknya. Mereka juga dianggap sering melakukan perbuatan bercorak moral hazard atau membuat kinerja elemen peradilan sekedar menjalankan peran abu-abu atau terbatas mempermainkan kata-kata hukum, sementara dalam realitas, negara hukum yang seharusnya berbasis konstitusionaltas dibuatnya terdistorsi konstruksinya, atau bahkan dibuatnya menjadi terdegradasi substansialnya, sehingga lebih tampak sebagai wujud negara hukum formal.
Pengaruh paham liberal dari JJ. Rousseau, Stahl menyusun negara hukum formal dengan unsur-unsur sebagai berikut; 1) mengakui dan melindungi hak-hak asasi manusia, 2) untuk melindungi hak-hak asasi manusia, maka penyelenggaraan negara haruslah berdasarkan theory atau konsep trias politica, 3) alam melaksanakan tugasnya, pemerintah dibatasi oleh undang-undang (wetmating bestuur), dan 4) apabila dalam melaksanakan tugas pemerintah masih melanggar hak asasi, maka ada pengadilan administrasi yang mengadilinya. ${ }^{9}$

Berdasarkan konsep Stahl itu dapat diambil keimpulan bahwa negara hukum bertujuan untuk melindungi hak-hak asasi manusia dan membatasi kekuasaan terhadapnya. Konsep ini hanya mendahulukan aspek formalnya saja. Dan hasilnya membawa persamaan pada aspek politik dan sosial saja, tetapi dalam penyelenggaraan ekonomi, kemakmuran dan kesejahteraan rakyat memberi kesempatan bersaing secara bebas. Siapa yang kuat dialah yang dapat memenangkan keuntungan yang sebesar-besarnya bagi dirinya sendiri tanpa mementingkan kepentingan masyarakat. ${ }^{10}$ kepentingan masyarakat atau pencari keadilan hanya dijadikan sebagai obyek yang dipermainkan sesukanya.

Dalam logika itu, berarti ketika seseorang atau sejumlah orang bisa berlindung dibalik baju negara. Maka mereka ini bukan tidak mungkin akan atau mampu mendapatka keuntungan berlipat ganda, karena negara yang digunakan sebagai sandaran ini mempunyai kekuatan yang bersifat otoritatif, yang menjadikan segelintir orang bisa bertindak sesuka hatinya secara liberal.

Uang ribuan triliun rupiah sudah sekian lama dibawa lari keluar negeri oleh para penahat elitis atau yang bergelar berdasi seperti dalam kasus korupsi-korupsi klas gurita, sementara tangan-tangan pilar yudisial terbaca sering kurang jujur, independen, dan militan untuk menjaringnya. Kondisi paradoksal ini adalah sampel penyakit yang

\footnotetext{
9 Aziz Hakim, Abdul. (2011) Negara Hukum Dan Demokrasi di Indonesia, Yogyakarta; Pustaka Pelajar. Hlm. 16-17.

10 Ibid.
} 
menjadi duri idealitas terbentuknya negara hukum yang kuat.

Ekspektasi rakyat, mereka harus diburu dimanapun dan kemanapun, pasalnya mereka ini adalah para kleptokrat dan penoda besar terhadap nasionalisme. Jika mereka bisa diseret keseluruhan atas dasar prinsip egalitarian dalam akuntabilitas sistem peradilan pidana, maka upaya membangun negara kuat tidak omong kosong atau bangunan negara benar-benar didukung oleh kekuatan yang terus melakukan penguatannya.

Rakyat yang semestinya mendapatkan informasi secara terbuka dari elemen yudisial yang berkewajiban menenanganinya mengenai perjalanan kasus serius, yang merapuhkan perekonomina bangsa dan merendahkan marwah hukum negara itu, temyata tidak dipenuhi haknya. Akibatnya mereka makin berpraduga bersalah kalau keadilan terus saja dipermainkan. Sistem peradilan pidana yang seharusnya diperkuat untuk menjadi jalan memerangi atau menanggulangi penyakit serius, justru menjadi penyakit tersendiri yang membutuhkan untuk disembuhkan.

Merestorasi praktik sistem peradilan yang benar-benar memberikan keadilan merupakan "obat" mujarab yang bisa menyejukkan kondisi psikologis masyarakat. Sistem peradilan pidana yang diperkuat oleh aparat pengimplementasinya akan membuat pihakpihak yang biasanya menjadi virus, akan bisa ditanggulanginya. Hal ini sangat ditentukan oleh peran maksimal aparat yudisial. Bilamana mereka sungguh-sungguh merestorasinya, maka nawa cita Presiden Jokowi dalam membangun negara kuat bisa terwujud.

Aparat yudisial dalam menjalankan sistem peradilan pidana dituntut penyelarasan antara apa yang diperbuat dengan perintah konstitusi. Sepanjang prinsip konstitusionalitas dipegang teguh, maka tidak ada kondisi negara yang tidak bisa disembuhkan. Prinsip konstitusionalitas bernegara, termasuk diantaranya dalam mewujudkan prinsip peradilan pidana yang terbuka, haruslah menjadi prinsip yang benar-benar menghidupkan ekspektasi pencari keadilan.

\section{KESIMPULAN}

Di era reformasi ini, negara (Indonesia) terus berupaya membangun dirinya supaya menjadi negara hukum yang kuat. Ada berbagai macam hambatan atau tantangan yang ditemui oleh setiap aparat penegak hukum dalam upaya membangun negara ini. Ada yang konsisten mempertahankan integritas dirinya, namun ada pula yang gagal menjaga amanat yang dipercayaka negara padanya.

Terbukti, banyak aparat penegak hukum atau pilar-pilar yudisial yang gagal menunjukkan dirinya sebagai aparat yang punya komitmen dalam salah satu cita dari Nawa Cita Presiden Joko Widodo itu. Penyelenggaraan sistem peradilan pidana (criminal justice system) merupakan bagian dari sistem hukum Indonesia yang seringkali sebagian diantaranya diposisikan publik belum berhasil mewujudkan cita-cita itu akibat para penyelenggaranya yang belum menjalankan prinsip konstitusionalitas dalam kinerjanya. Perkara pidana seperti korupsi atau kasus-kasus yang belum ditempatkannya sebagai amanat istimewa, dan sebaliknya ditempatka sebagai obyek yang menguntungkannya.

\section{DAFTAR PUSTAKA \\ Peraturan Perundang-undangan}

Universal Declaration of Human Right

\section{Buku}

Aziz Hakim, Abdul. 2011, Negara Hukum Dan Demokrasi Di Indonesia, Yogyakarta: Pustaka Pelajar.

Russel, Bertrand. 2002, Sejarah Filssafat Barat, Yogyakarta: Pustaka Pelajar.

Harper, Erica. 2009, International law and standard applicable in natural disaster situation, Jakarta: Gramedia.

Gwendolen M. Carter dan John Herz, 1982, Peranan Pemerintah dalam Masyarakat Masa Kini, dalam Miriam Budiardjo, Masalah Kenegaraan, Jakarta: Gramedia. 
Saksono, Haryo. 2018, Membangun Negeri Untuk Rakyat, Jakarta: Gerbang Ilmu.

Asshiddiqie, Jimly. 2005, Konstitusi dan Konstitusionalisme Indonesia, Edisi Revisi,Jakarta: Konstitusi Press.

2008, Menuju Negara

Hukum Yang Demokratis, Jakarta: Sekretariat Jendera dan Kepaniteraan Mahkamah Konstiusi.

Suhardiman, 2016, "Eksaminasi Membangun Era Baru Bernegara", Lembaga Kajian Strategis Indonesia (LKSI), Surabaya, 16 Mei 2016. 